\begin{tabular}{|c|c|c|c|c|c|c|}
\hline \multirow{4}{*}{ Impact Factor: } & ISRA (India) & $=3.117$ & SIS (USA) & $=0.912$ & ICV (Poland) & $=6.630$ \\
\hline & ISI (Dubai, UAE & $=0.829$ & РИНЦ (Russia & $=0.156$ & PIF (India) & $=1.940$ \\
\hline & GIF (Australia) & $=0.564$ & ESJI (KZ) & $=8.716$ & IBI (India) & $=4.260$ \\
\hline & JIF & $=1.500$ & SJIF (Morocco & $=5.667$ & OAJI (USA) & $=0.350$ \\
\hline
\end{tabular}

\begin{tabular}{|c|c|}
\hline $\begin{array}{l}\text { SOI: } \underline{1.1 / \mathrm{TA}} \\
\text { International Sc } \\
\text { Theoretical } \boldsymbol{\&} \mathbf{A}\end{array}$ & $\begin{array}{l}\frac{S}{\text { DOI: }} \text { 10.15863/TAS } \\
\text { ientific Journal } \\
\text { pplied Science }\end{array}$ \\
\hline p-ISSN: 2308-4944 (print) & e-ISSN: 2409-0085 (online) \\
\hline Year: $2019 \quad$ Issue: 05 & Volume: 73 \\
\hline Published: 15.05 .2019 & http://T-Science.org \\
\hline
\end{tabular}

SECTION 7. Mechanics and machine construction.
QR - Issue

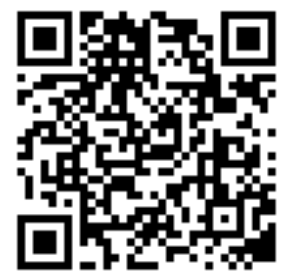

M.Sc.Eng., Corresponding Member of International Academy of Theoretical and Applied Sciences, Lecturer of Vladimir Industrial College, Russian Federation https://orcid.org/0000-0002-2747-552X chemezov-da@yandex.ru

Irina Pavluhina Lecturer of Vladimir Industrial College, Russian Federation

Oleg Gorbatenko Master of Industrial Training, Vladimir Industrial College, Russian Federation

Ivan Mochalov Lecturer of Vladimir Industrial College, Russian Federation

Evgeniy Pavlov Student of Vladimir Industrial College, Russian Federation

Oksana Dubova Student of Vladimir Industrial College, Russian Federation

Elena Kiseleva Master of Industrial Training, Vladimir Industrial College, Russian Federation

Elena Lezova Master of Industrial Training, Vladimir Industrial College, Russian Federation

\title{
MANUFACTURING OF A CASE-SHAPED PART IN CONDITIONS OF SHEET STAMPING
}

Abstract: A rational technology of manufacturing of a thin-walled case-shaped part by sheet stamping is presented in the article. Stages of deep drawing of a sheet billet in conditions of automated production were considered. Description and operating principle of technological equipment devices are given. An analysis of reject of a product at realization of the considered technological process of drawing was performed.

Key words: drawing, a sheet billet, a die, a part, a step.

Language: English

Citation: Chemezov, D., et al. (2019). Manufacturing of a case-shaped part in conditions of sheet stamping. ISJ Theoretical \& Applied Science, 05 (73), 51-64.

Soi: http://s-o-i.org/1.1/TAS-05-73-11 Doi: crossef https://dx.doi.org/10.15863/TAS.2019.05.73.11 


\begin{tabular}{|c|c|c|c|c|c|c|}
\hline \multirow{4}{*}{ Impact Factor: } & ISRA (India) & $=3.117$ & SIS (USA) & $=0.912$ & ICV (Poland) & $=6.630$ \\
\hline & ISI (Dubai, UAI & $=0.829$ & РИНЦ (Russia & $=0.156$ & PIF (India) & $=1.940$ \\
\hline & GIF (Australia) & $=0.564$ & ESJI (KZ) & $=8.716$ & IBI (India) & $=4.260$ \\
\hline & JIF & $=1.500$ & SJIF (Morocco & $=5.667$ & OAJI (USA) & $=0.350$ \\
\hline
\end{tabular}

\section{Introduction}

Researches of a deep drawing process of sheet billets by direct and reverse methods are presented in the works $[1-13]$. In these works, there were paid attention to the questions of wrinkling on a flange, plastic deformation of material and etc. from thickness of the sheet billet at drawing (one step). Thin-walled hollow parts of a complex shape are performed by multi-step drawing. This process of plastic deformation consists in gradual changing of the shape of the sheet billet before obtaining of a finished product. At such processing conditions, material is exposed to significant deformation, especially at bend. For reducing of material friction of the sheet billet about of forming tools surfaces of a drawing die, it is necessary to use lubricating fluids in a large volume. So as maximum plastic deformation of the sheet billet occurs at the first steps of drawing then it is rational to use the combined dies. Efficiency of multi-step plastic deformation of the (metal) sheet billets in conditions of automated production is provided at choosing of an optimal design of special devices (the dies) and observing of sheet stamping modes.

\section{Technology}

The technological process of multi-step drawing of the sheet billet was subjected to consideration. The billets made of the cold-rolled sheet of normal rolling accuracy in thickness (the sheet with the high surface finish for complex drawing made of low-carbon quality steel) were exposed to plastic deformation. The sizes of a steel band were: thickness $-2.5 \mathrm{~mm}$, the width $-1250 \mathrm{~mm}$, and the length $-2500 \mathrm{~mm}$ in accordance with GOST 19904-90 [14].

The sheet billets are cut down on the operation 010 of the technological process of manufacturing of the part "Case". Cutting down of the sheet billet is carried out by means of the cutting die on the double column crank press. Required force of the press is 100 tf, a double-stroke number is 90 . For implementation of the cutting down process of the sheet billets, it is necessary to use industrial oil I-20A (GOST 2079988 ) and thread (yarn) waste (industry standard 178886 ). Work on the press is carried out in the mode of single strokes with foot switch. The sheet billets are folded in a plastic container. The sizes of the sheet billet are provided by the tool. Quality control of appearance of the sheet billet is performed visually. Nesting pattern of the steel band and the sizes of the sheet billet after cutting down on the press are presented in the Fig. 1. The sign * on the sketch of nesting pattern of the steel band is the linear size for reference. On the flange of the sheet billet after cutting down must not be chips and other mechanical damage.
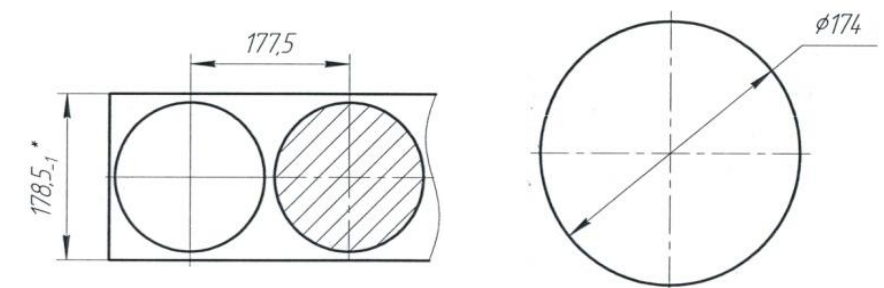

A)

B)

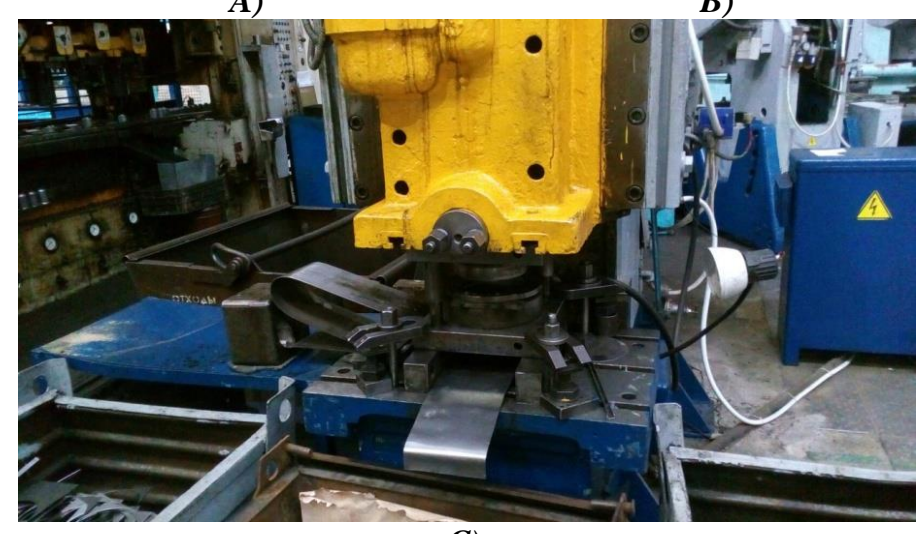

C)

Figure 1 - Obtaining of the sheet billet for multi-step drawing: $A$ - nesting pattern of the steel band, $B$ - the shape and the size of the sheet billet, $C$ - the double column crank press.

Multi-step drawing of the case-shaped part is performed on the eight-position automatic press "Paust-320". The general view and the technical parameters of the automatic press "Paust-320" are presented in the table 1 .
Maximum force of the press is $320 \mathrm{tf}$, the doublestroke number is $16-32$.

Staged changing of the shape of the sheet billet during plastic deformation on the operation 015 of the technological process of manufacturing of the part "Case" is presented in the Fig. 2. 


\begin{tabular}{llllll} 
& ISRA (India) $=\mathbf{3 . 1 1 7}$ & SIS (USA) & $=\mathbf{0 . 9 1 2}$ & ICV (Poland) & $=\mathbf{6 . 6 3 0}$ \\
Impact Factor: & ISI (Dubai, UAE) $=\mathbf{0 . 8 2 9}$ & PUHL (Russia) $=\mathbf{0 . 1 5 6}$ & PIF (India) & $=\mathbf{1 . 9 4 0}$ \\
& GIF (Australia) $=\mathbf{0 . 5 6 4}$ & ESJI (KZ) & $=\mathbf{8 . 7 1 6}$ & IBI (India) & $=\mathbf{4 . 2 6 0}$ \\
& JIF & $\mathbf{1 . 5 0 0}$ & SJIF (Morocco) $=\mathbf{5 . 6 6 7}$ & OAJI (USA) & $\mathbf{0 . 3 5 0}$ \\
\hline
\end{tabular}

Table 1. The general view and the technical parameters of the automatic press "Paust-320".

\begin{tabular}{|c|c|}
\hline Parameter & Value \\
\hline Maximum force of slider (at distance of $15 \mathrm{~mm}$ to end of stroke) & $250 \mathrm{tf}$ \\
\hline $\begin{array}{l}\text { Allowable force related in one position: } \\
\text { - side slider } \\
\text { - other positions }\end{array}$ & $\begin{array}{l}70 \mathrm{tf} \\
80 \mathrm{tf}\end{array}$ \\
\hline Maximum depth of drawing & $140 \mathrm{~mm}$ \\
\hline Stroke length of slider & $420 \mathrm{~mm}$ \\
\hline Number of strokes (stepless adjustment) & $16-32$ \\
\hline Number of positions & 8 \\
\hline Distance between individual positions & $400 \mathrm{~mm}$ \\
\hline Adjustment of die holders & $80 \mathrm{~mm}$ \\
\hline Stroke of main slider & $420 \mathrm{~mm}$ \\
\hline $\begin{array}{l}\text { Maximum distance between work table and die holders in the lowest position of } \\
\text { slider (die holders at top) }\end{array}$ & $750 \mathrm{~mm}$ \\
\hline Sizes of clamped surface of die holder & $390 \times 400 \mathrm{~mm}$ \\
\hline Thickness of die plate & $80 \mathrm{~mm}$ \\
\hline Level height of transportation above surface of work table & $480 \mathrm{~mm}$ \\
\hline Sizes of clamped surface of die plate & $3300 \times 1000 \mathrm{~mm}$ \\
\hline Maximum width of steel band (thickness of steel band for feed of $2 \mathrm{~mm}$ ) & $500 \mathrm{~mm}$ \\
\hline Maximum feed step of steel band in one stroke & $400 \mathrm{~mm}$ \\
\hline Maximum diameter of round workpiece & $375 \mathrm{~mm}$ \\
\hline Way of opening of each clamshell guide & $80-120 \mathrm{~mm}$ \\
\hline Maximum diameter of round workpiece at staggered arrangement & $265 \mathrm{~mm}$ \\
\hline $\begin{array}{l}\text { Distance between work table and side slider at the lowest position of slider and } \\
\text { the highest position of adjustment mechanism }\end{array}$ & $980 \mathrm{~mm}$ \\
\hline Maximum transverse displacement at staggered arrangement & $240 \mathrm{~mm}$ \\
\hline Distance between clamshell guides in closed state & $320-400 \mathrm{~mm}$ \\
\hline Power of main electric motor & $63 \mathrm{~kW}$ \\
\hline Feed rate of steel band & $\begin{array}{l}10 \text { and } 15 \mathrm{~m} \text { per } \\
\text { minute }\end{array}$ \\
\hline Sizes of fitment bore in die holders and side slider & $\varnothing 80 \mathrm{H} 8$ \\
\hline 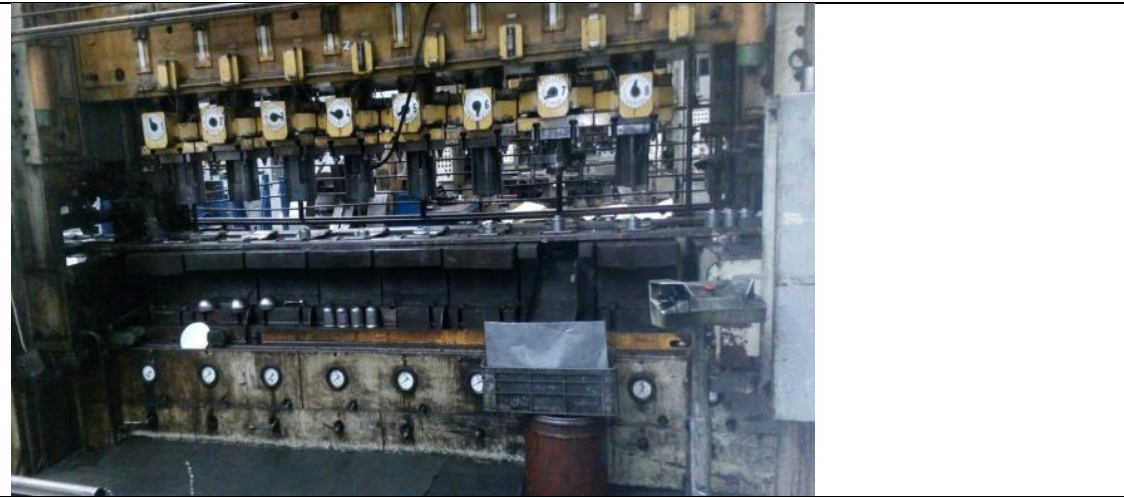 & \\
\hline
\end{tabular}




\begin{tabular}{|c|c|c|c|c|c|c|}
\hline \multirow{4}{*}{ Impact Factor: } & ISRA (India) & $=3.117$ & SIS (USA) & $=0.912$ & ICV (Poland) & $=6.630$ \\
\hline & ISI (Dubai, UAE & $=0.829$ & РИНЦ (Russia & $=0.156$ & PIF (India) & $=1.940$ \\
\hline & GIF (Australia) & $=0.564$ & ESJI (KZ) & $=8.716$ & IBI (India) & $=4.260$ \\
\hline & JIF & $=1.500$ & SJIF (Morocce & $=5.667$ & OAJI (USA) & $=0.350$ \\
\hline
\end{tabular}

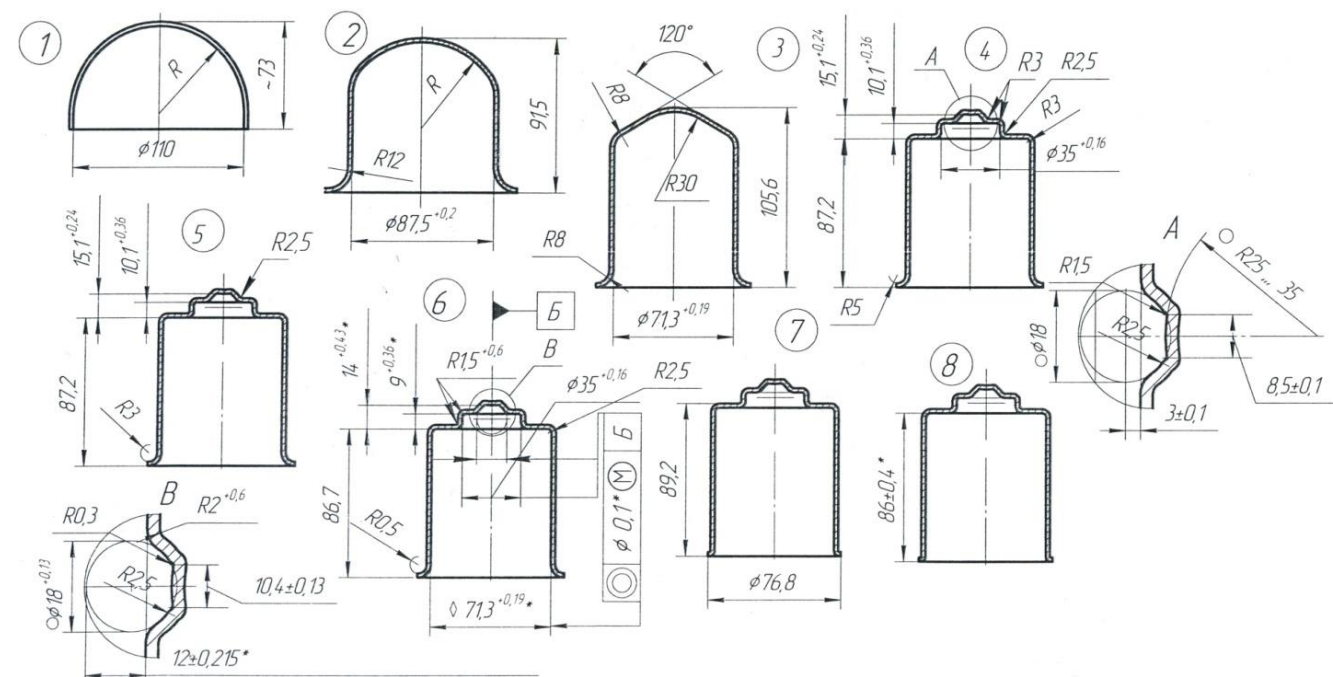

Figure 2 - The operation steps of drawing of the part "Case".

The sign * is the controlled size. The other sizes of the case-shaped part are provided by the forming tool. The size of $12 \pm 0.215 \mathrm{~mm}$ is controlled by the steel ball 19-20 GOST 3722-81 after the sixth step of the sheet billet drawing.

During deep drawing of the sheet billet there are used technological lubricant "Rosoil-SHOCK" TS 0258-001-06377289-94 (or substitute material "Lycopodium" GOST 22226-76) and thread (yarn) waste (industry standard 1788-86).

Drawing of the sheet billet consists of the combined steps: 1 step - to pull the sheet billet the first time, 2 step - to pull the sheet billet the second time, 3 step - to pull the sheet billet the third time, 4 step to calibrate the sheet billet the first time, 5 step - to calibrate the sheet billet the second time, 6 step - to calibrate the sheet billet the third time, 7 step - to trim the flange, 8 step - to calibrate the sheet billet in the height size.

Control of the sizes is carried out by the following measuring tools: the inner diameter $71.3^{+0.19}$ $\mathrm{mm}$ (the plug gauge), the inner diameter $35^{+0.16} \mathrm{~mm}$ (the plug gauge $8133-094935 \mathrm{H} 11$ ), the size $9^{+0.36} \mathrm{~mm}$ (the special control device), the size $14^{+0.43} \mathrm{~mm}$ (the special device for control), a sphere (the special device), coaxiality of 0.1 (a control template), the size $86 \pm 0.4 \mathrm{~mm}$ (the electronic depth gauge 200-0.01 GOST 162-90).
Multi-step drawing of the sheet billet is performed in the special dies. Durability of the each die is 850000 hits. The remaining technical requirements for manufacturing of the dies are performed in accordance with the proprietary standard 453 091-80.

The assembly drawing of the die for performing of the first step of drawing of the part "Case" is presented in the Fig. 3.

Formation of the part contour is carried out during vertical displacement of the die 1 concerning to the punch 4 . The sheet billet is placed between the contact surfaces of the die and the punch. The punch is clamped to the holder 16 by means of four bolts 25 . Clamping of the upper 10 and lower 13 plates of the die is carried out by the screws 24 and 26. The spherical surface is formed at contact of the takeout surface 7 with the sheet billet. Specified drawing force is provided by the spring 29 and the screw plug 30 . The unstucker 6 prevents adhesion of the sheet billet surface to the takeout. Drawing force is set by the pusher 18 , and stroke of the movable part of the press is set by the bolt 22 and the nuts 27,28 . Displacement of the processed sheet billet in a removal zone is performed by the puller 14 by means of the pusher 31 . The die has the bush 5 for displacement direction of the takeout. The clamp 15 orients the cover 12 and the puller. Clamping of the clamp is carried out by the screw 23. 


\begin{tabular}{llllll} 
& ISRA (India) $=\mathbf{3 . 1 1 7}$ & SIS (USA) & $=\mathbf{0 . 9 1 2}$ & ICV (Poland) & $=\mathbf{6 . 6 3 0}$ \\
Impact Factor: & ISI (Dubai, UAE) $=\mathbf{0 . 8 2 9}$ & PUHL (Russia) $=\mathbf{0 . 1 5 6}$ & PIF (India) & $=\mathbf{1 . 9 4 0}$ \\
& GIF (Australia) $=\mathbf{0 . 5 6 4}$ & ESJI (KZ) $=\mathbf{8 . 7 1 6}$ & IBI (India) & $=\mathbf{4 . 2 6 0}$ \\
& JIF & $\mathbf{1 . 5 0 0}$ & SJIF (Morocco) $=\mathbf{5 . 6 6 7}$ & OAJI (USA) & $\mathbf{0 . 3 5 0}$ \\
\hline
\end{tabular}
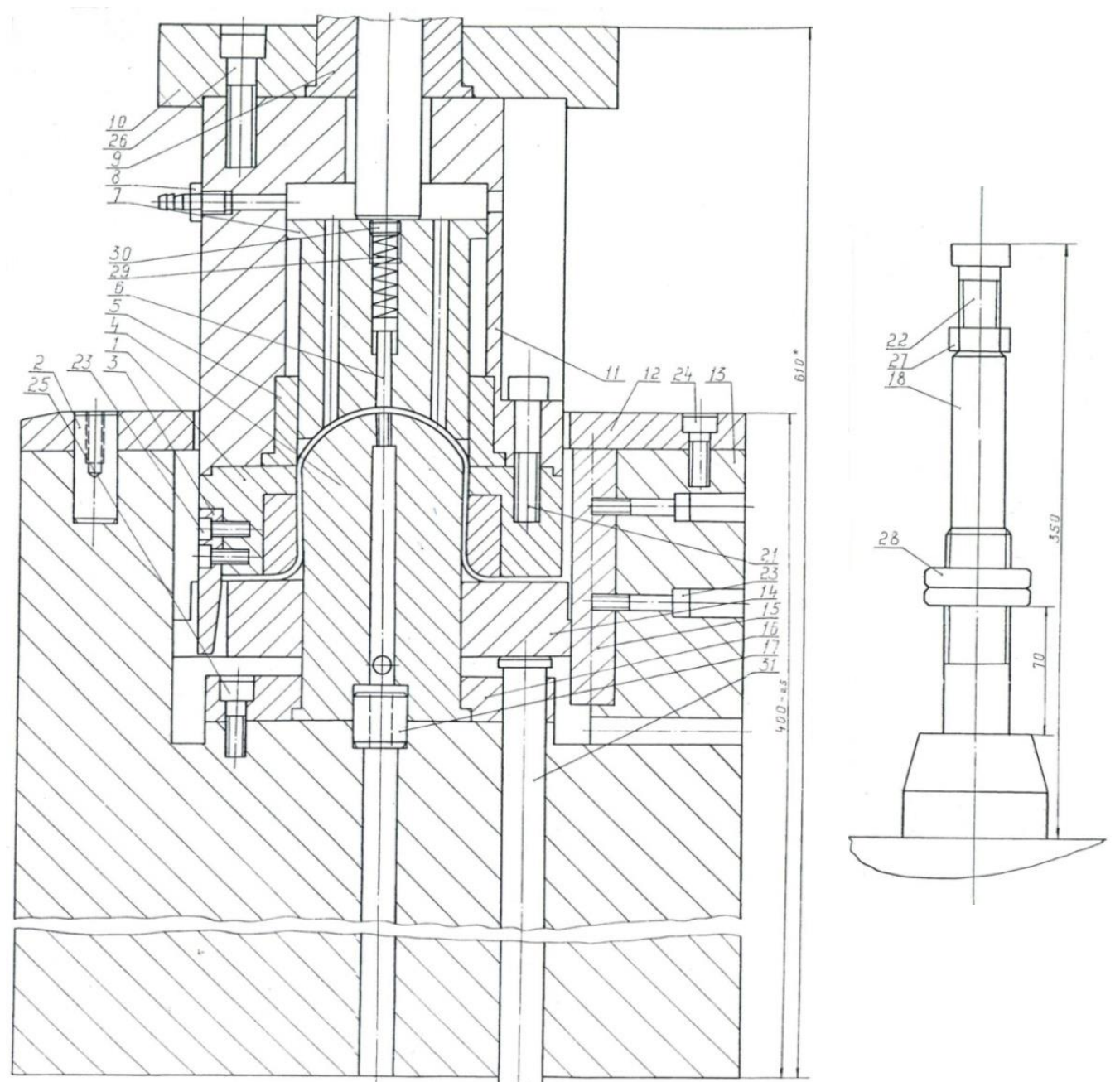

Figure 3 - The assembly drawing of the die for performing of the first step of the part drawing. 


\begin{tabular}{|c|c|c|c|c|c|c|}
\hline \multirow{4}{*}{ Impact Factor: } & ISRA (India) & $=3.117$ & SIS (USA) & $=0.912$ & ICV (Poland) & $=6.630$ \\
\hline & ISI (Dubai, UAE & $=0.829$ & РИНЦ (Russia) & $=0.156$ & PIF (India) & $=1.940$ \\
\hline & GIF (Australia) & $=0.564$ & ESJI (KZ) & $=8.716$ & IBI (India) & $=4.260$ \\
\hline & JIF & $=1.500$ & SJIF (Morocco) & $=5.667$ & OAJI (USA) & $=0.350$ \\
\hline
\end{tabular}

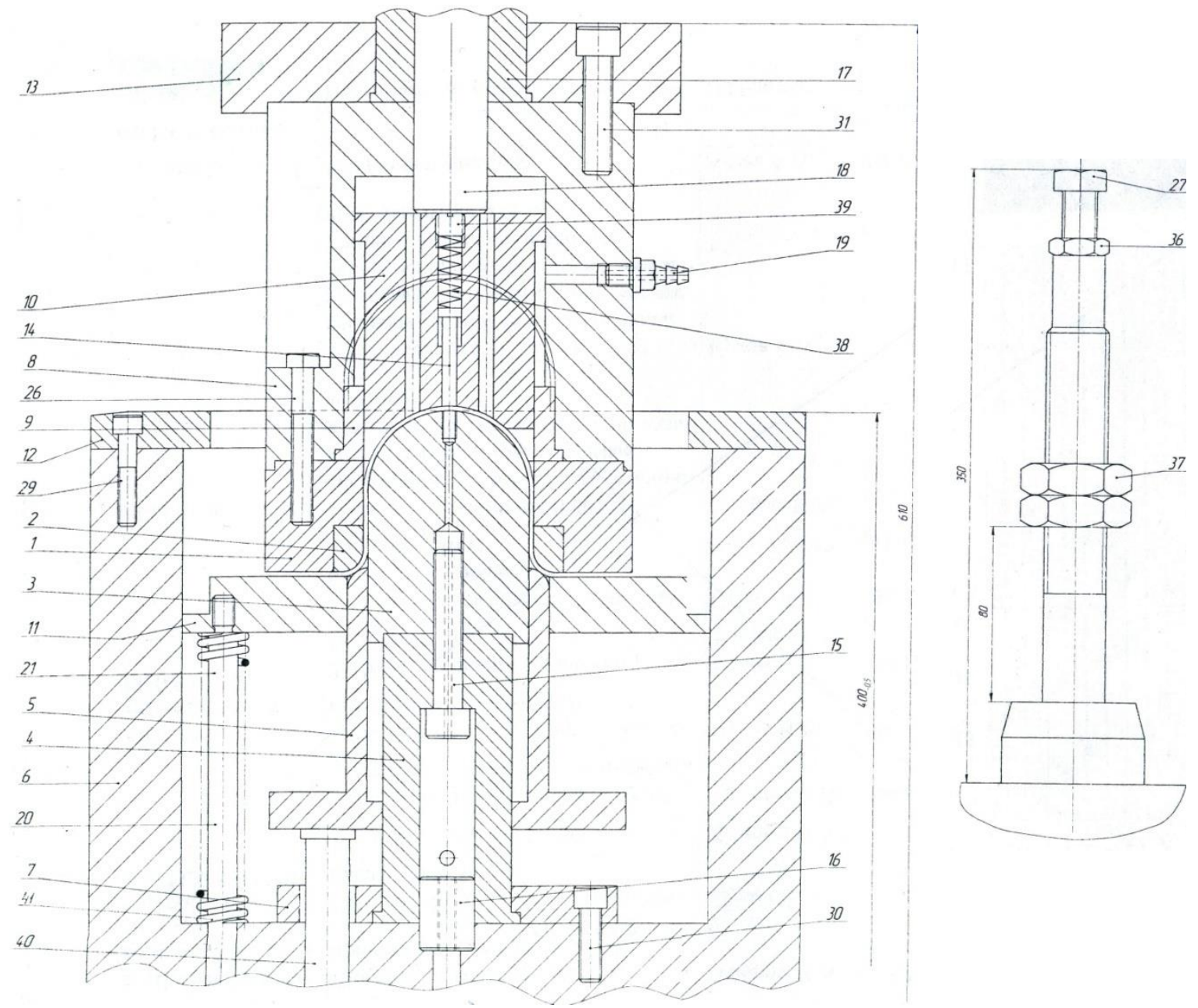

1 - die (1 piece),

2 - insert (1 piece),

3 - punch (1 piece),

4 - block (1 piece),

5 - blank holder (1 piece),

6 - lower plate (1 piece),

7 - holder (1 piece),

8 - retainer (1 piece),

9 - bush (1 piece),

10 - takeout (1 piece),

11 - puller (1 piece),

12 - cover (1 piece),

13 - upper plate (1 piece),

14 - unstucker (1 piece),

15 - screw (1 piece),

16 - clamp (1 piece),
17 - shank (1 piece),

18 - pusher (1 piece),

19 - connection (1 piece),

20 - column (4 pieces),

26 - bolt M12×80 (4 pieces),

27 - bolt M20×100 (1 piece),

29 - screw M10×30 (4 pieces),

30 - screw M12×35 (4 pieces),

31 - screw M16 $\times 50$ (4 pieces),

36 - nut M20 (1 piece),

37 - nut M36 (2 pieces),

38 - spring (1 piece),

39 - plug M16×1.5 (1 piece),

40 - pusher $\varnothing 24$ (4 pieces),

41 - spring (4 pieces).

Figure 4 - The assembly drawing of the die for performing of the second step of the part drawing. 


\begin{tabular}{llllll} 
& ISRA (India) $=\mathbf{3 . 1 1 7}$ & SIS (USA) & $=\mathbf{0 . 9 1 2}$ & ICV (Poland) & $=\mathbf{6 . 6 3 0}$ \\
Impact Factor: & ISI (Dubai, UAE) $=\mathbf{0 . 8 2 9}$ & PUHL (Russia) $=\mathbf{0 . 1 5 6}$ & PIF (India) & $=\mathbf{1 . 9 4 0}$ \\
& GIF (Australia) $=\mathbf{0 . 5 6 4}$ & ESJI (KZ) $=\mathbf{8 . 7 1 6}$ & IBI (India) & $=\mathbf{4 . 2 6 0}$ \\
& JIF & $\mathbf{1 . 5 0 0}$ & SJIF (Morocco) $=\mathbf{5 . 6 6 7}$ & OAJI (USA) & $\mathbf{0 . 3 5 0}$ \\
\hline
\end{tabular}

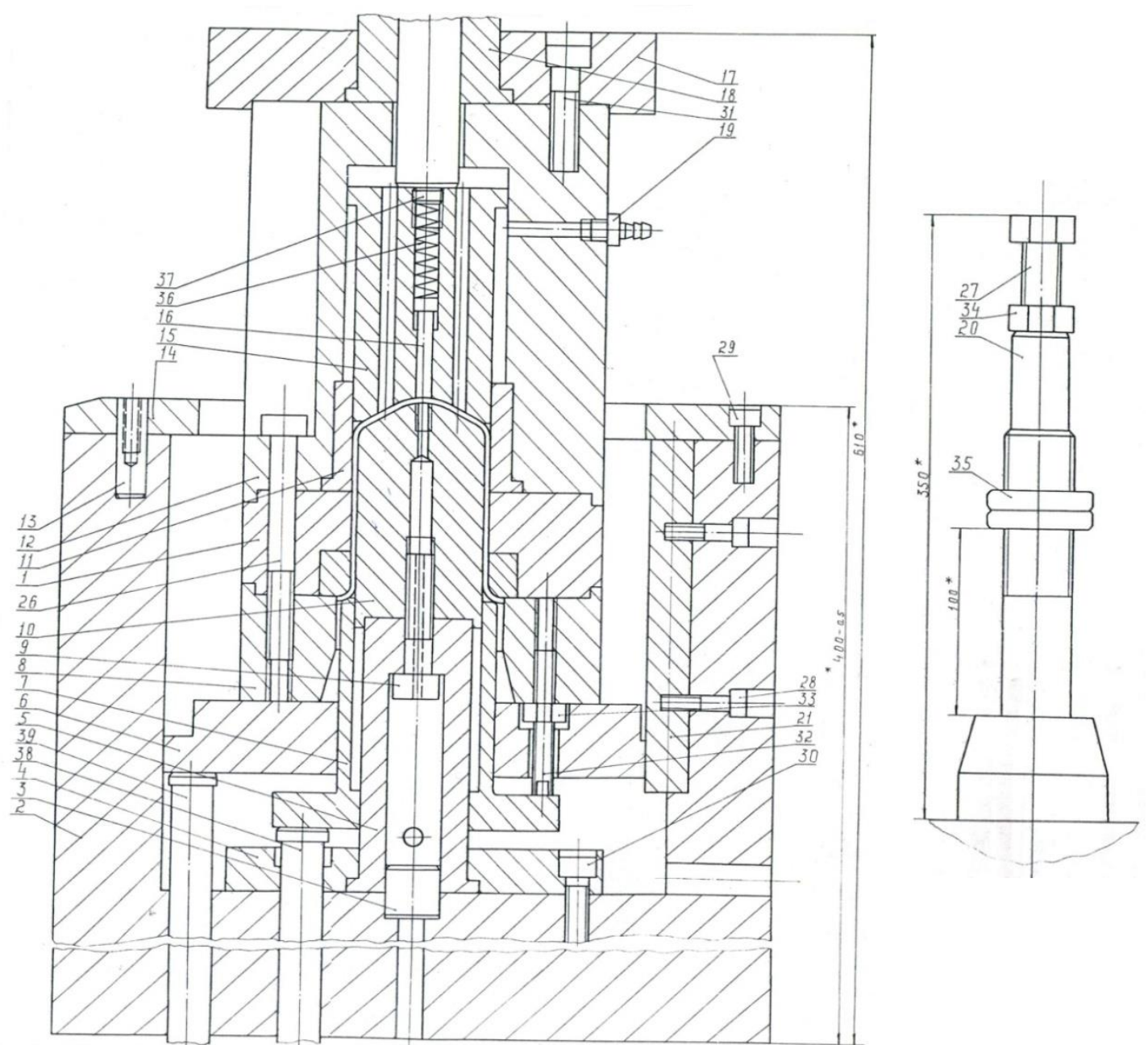

$1-\operatorname{die}(1$ piece),

2 - lower plate (1 piece),

3 - clamp (1 piece),

4 - holder (1 piece),

5 - block (1 piece),

6 - puller (1 piece),

7 - blank holder (1 piece),

8 - throwout collar (1 piece),

9 - screw (1 piece),

10 - punch (1 piece),

11 - bush (1 piece),

12 - retainer (1 piece),

13 - pin (2 pieces),

14 - cover (1 piece),

15 - takeout (1 piece),

16 - unstucker (1 piece),

17 - upper plate (1 piece),

18 - shank (1 piece),
19 - connection (1 piece),

20 - pusher (1 piece),

21 - clamp (1 piece),

26 - bolt M12×115 GOST 7805-70 (4 pieces),

27 - bolt M20 $\times 100$ GOST 7805-70 (1 piece),

28 - screw M8 $\times 20$ GOST $11738-80$ ( 2 pieces),

29, 30, 31 - screws M10×30, M12×35, M16×55

GOST $11738-80$ (4 pieces),

32 - screw M12×70 GOST 8878-84 (3 pieces),

33, 34 - nuts M12 (3 pieces), M20 (1 piece) GOST 5929-70,

35 - nut M36 GOST 11871-88 (2 pieces),

36 - spring 1086-0795 GOST 18793-80 (1 piece, $\varnothing 1 \times 12 \times 60$ ),

37 - plug 7009-0231 GOST 12202-66 (1 piece, M16×1.5),

38, 39 - pusher Ø24 Proprietary Standard 453.423-

82 (4 pieces, $\mathrm{L}=260_{-0.5}, \mathrm{~L}=360_{-0.5}$ ).

Figure 5 - The assembly drawing of the die for performing of the third step of the part drawing. 


\begin{tabular}{llllll} 
& ISRA (India) $=\mathbf{3 . 1 1 7}$ & SIS (USA) & $=\mathbf{0 . 9 1 2}$ & ICV (Poland) & $=\mathbf{6 . 6 3 0}$ \\
Impact Factor: & ISI (Dubai, UAE) $=\mathbf{0 . 8 2 9}$ & PUHL (Russia) $=\mathbf{0 . 1 5 6}$ & PIF (India) & $=\mathbf{1 . 9 4 0}$ \\
& GIF (Australia) $=\mathbf{0 . 5 6 4}$ & ESJI (KZ) $=\mathbf{8 . 7 1 6}$ & IBI (India) & $=\mathbf{4 . 2 6 0}$ \\
& JIF & $\mathbf{1 . 5 0 0}$ & SJIF (Morocco) $=\mathbf{5 . 6 6 7}$ & OAJI (USA) & $\mathbf{0 . 3 5 0}$ \\
\hline
\end{tabular}
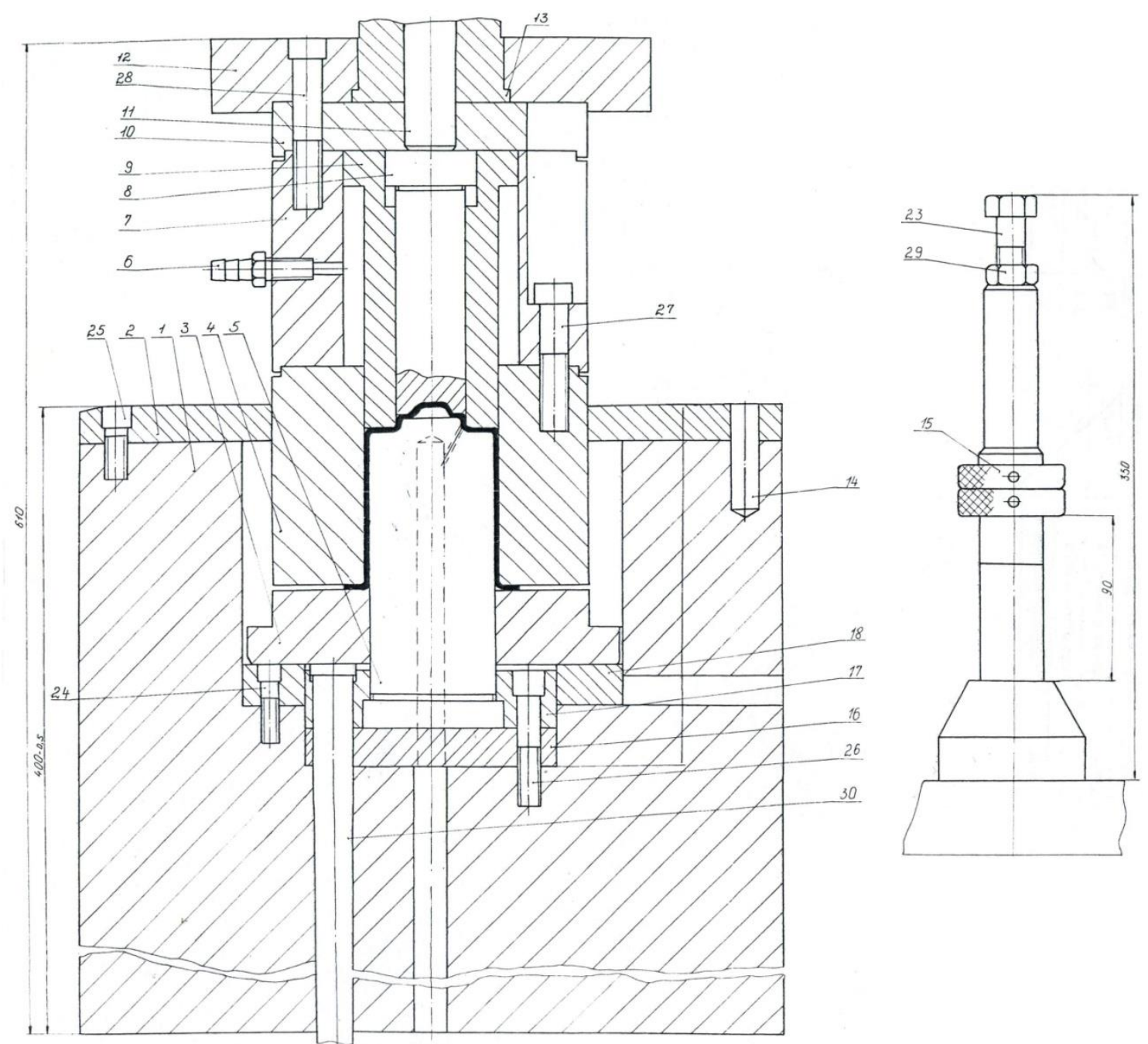

1 - lower plate (1 piece),

2 - cover (1 piece),

3 - puller (1 piece),

4 - die (1 piece),

5 - punch (1 piece),

6 - connection (1 piece),

7 - frame (1 piece),

8 - takeout (1 piece),

9 - takeout (1 piece),

10 - liner (1 piece),

11 - pusher (1 piece),

12 - upper plate (1 piece),

13 - shank (1 piece),

$14-\operatorname{pin}(2$ pieces),
15 - nut (2 pieces),

16 - plate (1 piece),

17 - holder (1 piece),

18 - ring (1 piece),

23 - bolt M20×75 GOST 7805-70 (1 piece),

24 - screw M10×30 GOST 11738-84 ( 2 pieces),

25 - screw M12×30 GOST 11738-84 (4 pieces),

26 - screw M12×60 GOST 11738-84 (4 pieces),

27 - screw M16×70 GOST 11738-84 ( 3 pieces),

28 - screw M16×80 GOST 11738-84 (3 pieces),

29 - nut M20 GOST 11871-88 (1 piece),

30 - pusher 1041-1201 GOST 18780-80 (4 pieces, before processing $\mathrm{L}=360$ ).

Figure 6 - The assembly drawing of the sizing die for performing of the fourth step of the part drawing. 


\begin{tabular}{llllll} 
& ISRA (India) $=\mathbf{3 . 1 1 7}$ & SIS (USA) & $=\mathbf{0 . 9 1 2}$ & ICV (Poland) & $=\mathbf{6 . 6 3 0}$ \\
Impact Factor: & ISI (Dubai, UAE) $=\mathbf{0 . 8 2 9}$ & PUHL (Russia) $=\mathbf{0 . 1 5 6}$ & PIF (India) & $=\mathbf{1 . 9 4 0}$ \\
& GIF (Australia) $=\mathbf{0 . 5 6 4}$ & ESJI (KZ) $=\mathbf{8 . 7 1 6}$ & IBI (India) & $=\mathbf{4 . 2 6 0}$ \\
& JIF & $\mathbf{1 . 5 0 0}$ & SJIF (Morocco) $=\mathbf{5 . 6 6 7}$ & OAJI (USA) & $\mathbf{0 . 3 5 0}$ \\
\hline
\end{tabular}
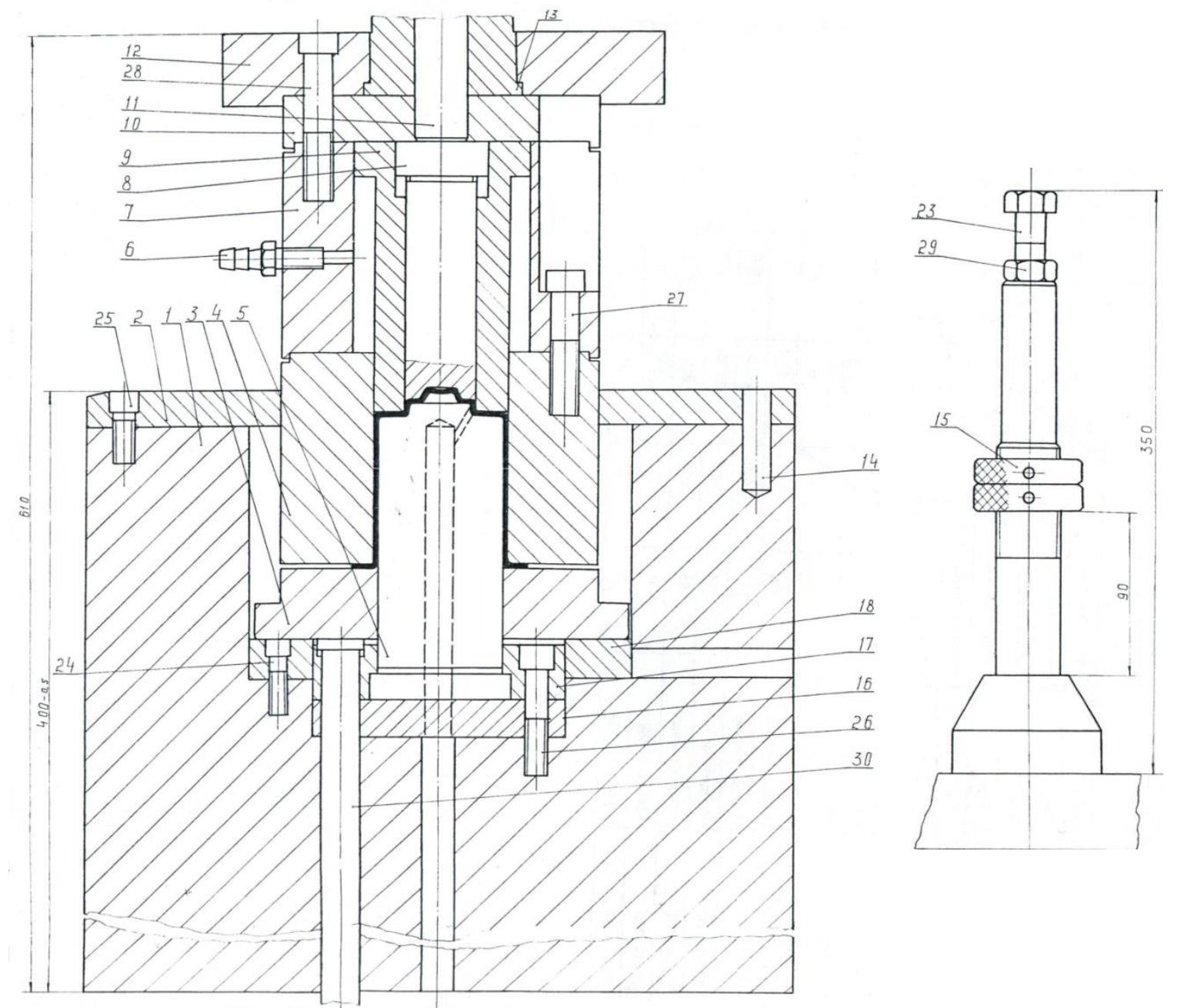

1 - lower plate (1 piece),

2 - cover (1 piece),

3 - puller (1 piece),

4 - die (1 piece),

5 - punch (1 piece),

6 - connection (1 piece),

7 - frame (1 piece),

8 - takeout (1 piece),

9 - takeout (1 piece),

10 - liner (1 piece),

11 - pusher (1 piece),

12 - upper plate (1 piece),

13 - shank (1 piece),

14 - pin (2 pieces),
15 - nut ( 2 pieces),

16 - plate (1 piece),

17 - holder (1 piece),

18 - ring (1 piece),

23 - bolt M20×75 GOST 7805-70 (1 piece),

24 - screw M10×30 GOST 11738-84 (2 pieces),

25 - screw M12×30 GOST 11738-84 (4 pieces),

26 - screw M12×60 GOST 11738-84 (4 pieces),

27 - screw M16×70 GOST 11738-84 (3 pieces),

28 - screw M16×80 GOST 11738-84 ( 3 pieces),

29 - nut M20 GOST 11871-88 (1 piece),

30 - pusher 1041-1201 GOST 18780-80 (4 pieces, before processing $\mathrm{L}=360$ ).

Figure 7 - The assembly drawing of the sizing die for performing of the fifth step of the part drawing. 


\begin{tabular}{|c|c|c|c|c|c|c|}
\hline \multirow{4}{*}{ Impact Factor: } & ISRA (India) & $=3.117$ & SIS (USA) & $=0.912$ & ICV (Poland) & $=6.630$ \\
\hline & ISI (Dubai, UAE & $=0.829$ & РИНЦ (Russia) & $=0.156$ & PIF (India) & $=1.940$ \\
\hline & GIF (Australia) & $=0.564$ & ESJI (KZ) & $=8.716$ & IBI (India) & $=4.260$ \\
\hline & JIF & $=1.500$ & SJIF (Morocco) & $=5.667$ & OAJI (USA) & $=0.350$ \\
\hline
\end{tabular}
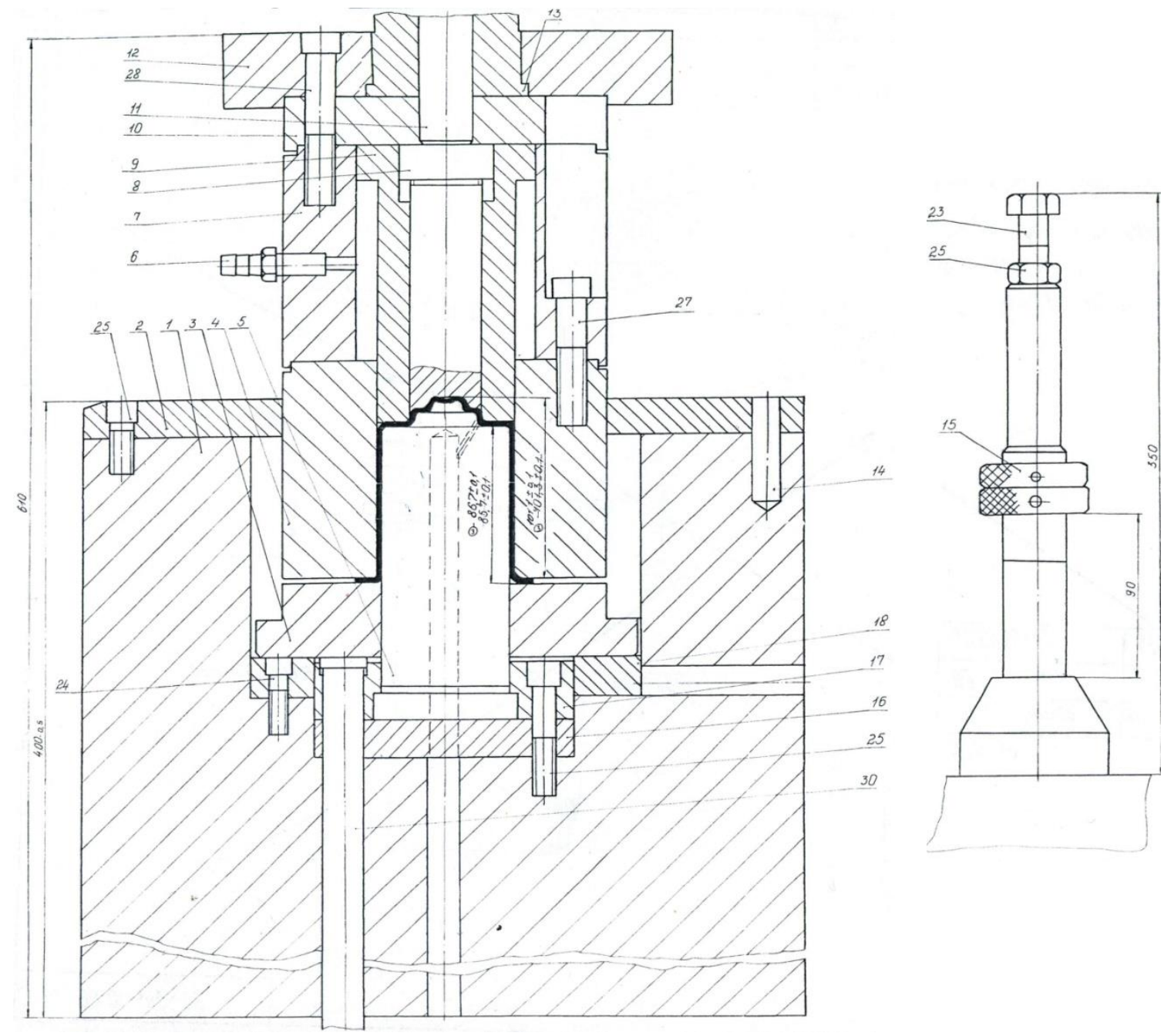

1 - lower plate (1 piece),

15 - nut ( 2 pieces),

2 - cover (1 piece),

16 - plate (1 piece),

3 - puller (1 piece),

17 - holder (1 piece),

4 - die (1 piece),

18 - ring (1 piece),

5 - punch (1 piece),

23 - bolt M20×75 GOST 7805-70 (1 piece),

6 - connection (1 piece),

24 - screw M10 GOST 11738-84 (2 pieces),

7 - frame (1 piece),

25 - screw M12×30 GOST 11738-84 (4 pieces),

8 - takeout (1 piece),

26 - screw M12×60 GOST 11738-84 (4 pieces),

9 - takeout (1 piece),

27 - screw M16×70 GOST 11738-84 ( 3 pieces),

10 - liner (1 piece),

28 - screw M16×80 GOST 11738-84 (3 pieces),

11 - pusher (1 piece),

29 - nut M20 GOST 11871-88 (1 piece),

12 - upper plate (1 piece),

30 - pusher 1041-1201 GOST 18780-80 (4 pieces,

13 - shank (1 piece),

before processing $\mathrm{L}=360$ ).

$14-\operatorname{pin}(2$ pieces),

Figure 8 - The assembly drawing of the sizing die for performing of the sixth step of the part drawing. 


\begin{tabular}{llllll} 
& ISRA (India) $=\mathbf{3 . 1 1 7}$ & SIS (USA) & $=\mathbf{0 . 9 1 2}$ & ICV (Poland) & $=\mathbf{6 . 6 3 0}$ \\
Impact Factor: & ISI (Dubai, UAE) $=\mathbf{0 . 8 2 9}$ & PUHL (Russia) $=\mathbf{0 . 1 5 6}$ & PIF (India) & $=\mathbf{1 . 9 4 0}$ \\
& GIF (Australia) $=\mathbf{0 . 5 6 4}$ & ESJI (KZ) $=\mathbf{8 . 7 1 6}$ & IBI (India) & $=\mathbf{4 . 2 6 0}$ \\
& JIF & $\mathbf{1 . 5 0 0}$ & SJIF (Morocco) $=\mathbf{5 . 6 6 7}$ & OAJI (USA) & $\mathbf{0 . 3 5 0}$ \\
\hline
\end{tabular}
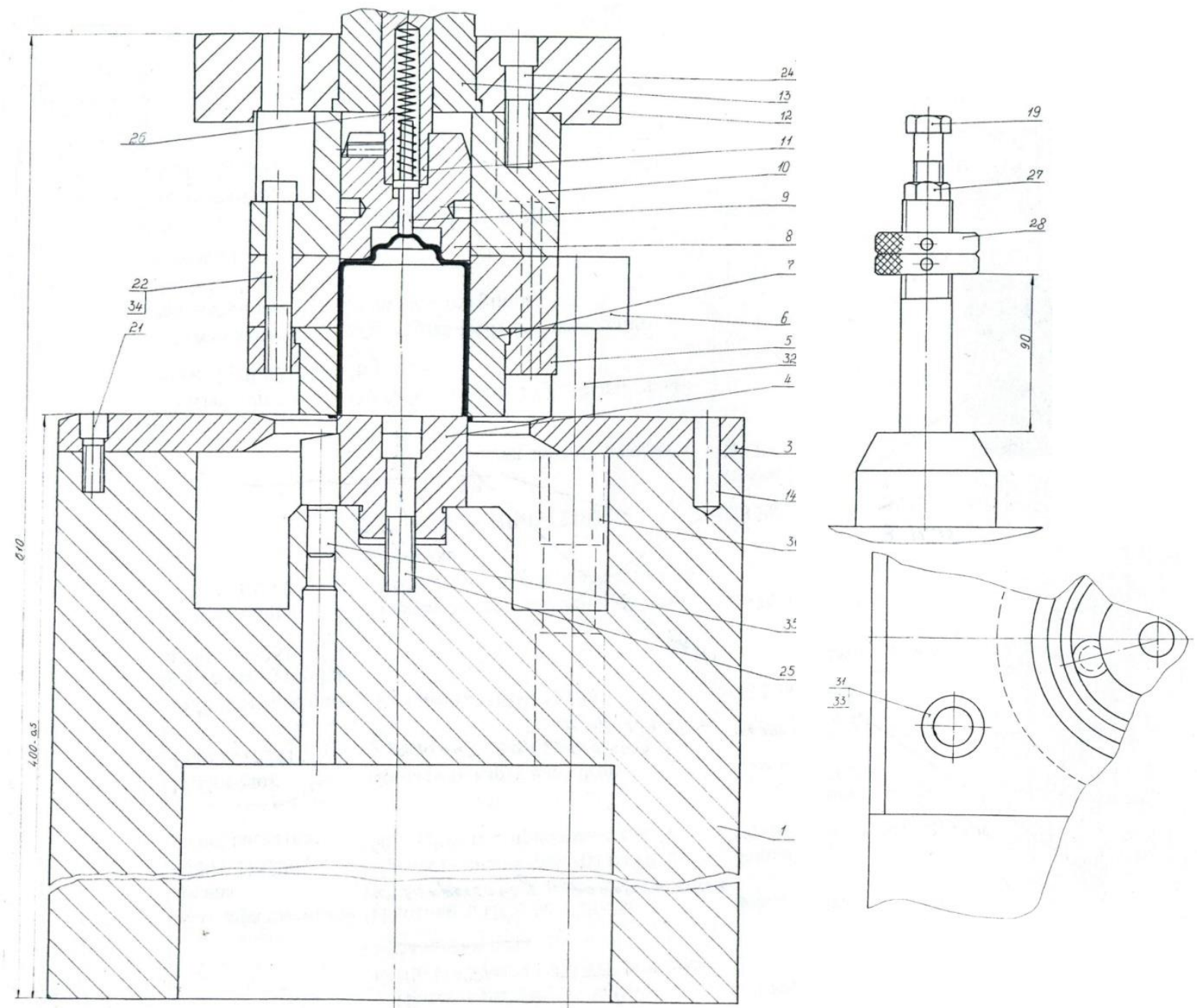

1 - lower plate (1 piece),

3 - cover (1 piece),

4 - punch (1 piece),

5 - holder (1 piece),

6 - plate (1 piece),

7 - die (1 piece),

8 - takeout (1 piece),

9 - unstucker (1 piece),

10 - case (1 piece),

11 - pusher (1 piece),

12 - plate (1 piece),

13 - shank (1 piece),

$14-\operatorname{pin}(2$ pieces),

15 - chute ( 2 pieces),

19 - bolt M20×70 GOST 805-70 (1 piece),

21 - screw M12×30 GOST 11738-84 (4 pieces),

22 - screw M10×30 GOST 11738-84 (4 pieces),
23 - screw M12×85 GOST 11738-84 (3 pieces), 24 - screw M16×55 GOST 11738-84 (3 pieces), 25 - screw M16×65 GOST 11738-84 (1 piece), 26 - spring 1086-0795 Proprietary Standard 453070-82 (1 piece, Ø2×12×80), 27 - nut M16×1.5-6H GOST 11871-88 (1 piece), 28 - nut M36×1.5-6H GOST 11871-88 (2 pieces), 30 - bush 1032-4166 Proprietary Standard 453241-80 (1 piece, 25L45),

31 - bush 1032-4175 Proprietary Standard 453241-80 (1 piece, 28L45),

32 - column 1030-4092 Proprietary Standard 453240-80 (1 piece, 25L150),

33 - column 1030-4117 Proprietary Standard 453240-80 (1 piece, 28L150),

34 - pin $12 \mathrm{~m} 6 \times 80$ GOST $3128-70$ (2 pieces),

35 - knive 1140-0153 GOST 18734-80 (2 pieces).

Figure 9 - The assembly drawing of the trimming die for performing of the seventh step of the part drawing. 


\begin{tabular}{llllll} 
& ISRA (India) $=\mathbf{3 . 1 1 7}$ & SIS (USA) & $=\mathbf{0 . 9 1 2}$ & ICV (Poland) & $=\mathbf{6 . 6 3 0}$ \\
Impact Factor: & ISI (Dubai, UAE) $=\mathbf{0 . 8 2 9}$ & PUHL (Russia) $=\mathbf{0 . 1 5 6}$ & PIF (India) & $=\mathbf{1 . 9 4 0}$ \\
& GIF (Australia) $=\mathbf{0 . 5 6 4}$ & ESJI (KZ) & $=\mathbf{8 . 7 1 6}$ & IBI (India) & $=\mathbf{4 . 2 6 0}$ \\
& JIF & $\mathbf{1 . 5 0 0}$ & SJIF (Morocco) $=\mathbf{5 . 6 6 7}$ & OAJI (USA) & $\mathbf{0 . 3 5 0}$ \\
\hline
\end{tabular}
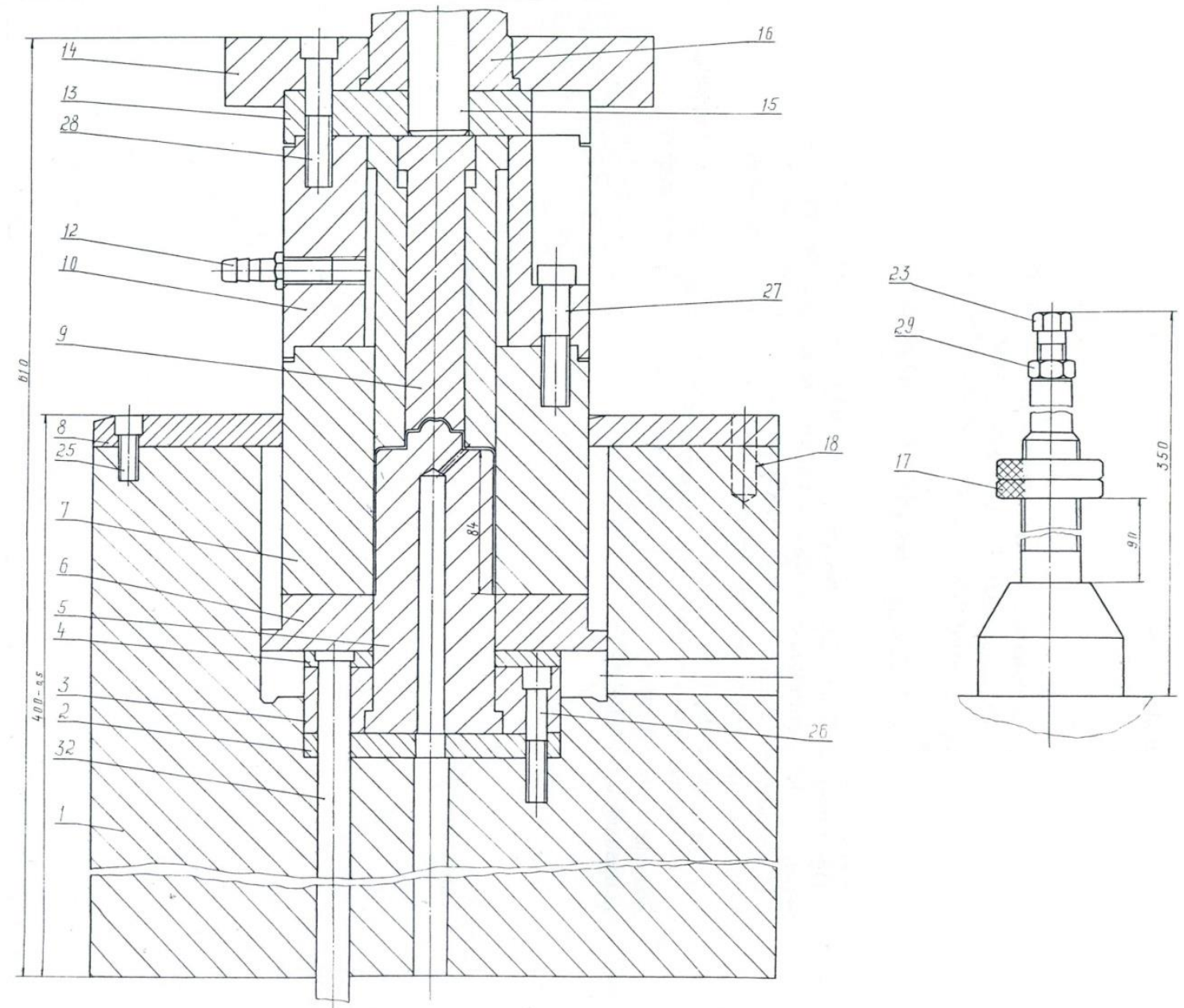

1 - lower plate (1 piece),

2 - plate (1 piece),

3 - holder (1 piece),

4 - ring (1 piece),

5 - punch (1 piece),

6 - puller (1 piece),

7 - die (1 piece),

8 - cover (1 piece),

9 - unstucker (1 piece),

10 - frame (1 piece),

11 - takeout (1 piece),

12 - connection (1 piece),

13 - liner (1 piece),

14 - upper plate (1 piece),

15 - pusher (1 piece),

16 - shank (1 piece),
17 - nut (2 pieces),

18 - pin (2 pieces),

23 - bolt M20×75 GOST 7805-70 (1 piece),

24 - screw M10×25 GOST 11738-84 ( 2 pieces),

25 - screw M12×30 GOST 11738-84 (4 pieces),

26 - screw M12×60 GOST 11738-84 (4 pieces),

27 - screw M16×70 GOST 11738-84 (3 pieces),

28 - screw M16×80 GOST 11738-84 (3 pieces),

29 - nut M20 GOST 11871-88 (1 piece),

30 - spring 1086-0795 GOST 19794-80 (1 piece, $\varnothing 1.6 \times 12 \times 110)$,

31 - plug 7009-0231 GOST 12202-66 (1 piece, M16),

32 - pusher 1041-1201 GOST 18780-80 (4 pieces, before processing $\mathrm{L}=360$ ).

\section{Figure 10 - The assembly drawing of the sizing die for performing of the eighth step of the part drawing.}

The assembly drawing of the die for performing of the second step of drawing of the part "Case" is presented in the Fig. 4. The assembly drawing of the die for performing of the third step of drawing of the part "Case" is presented in the Fig. 5. The assembly drawing of the sizing die for performing of the fourth step of drawing of the part "Case" is presented in the Fig. 6. The assembly drawing of the sizing die for performing of the fifth step of drawing of the part "Case" is presented in the Fig. 7. The assembly drawing of the sizing die for performing of the sixth step of drawing of the part "Case" is presented in the 


\begin{tabular}{|c|c|c|c|c|c|c|}
\hline \multirow{4}{*}{ Impact Factor: } & ISRA (India) & $=3.117$ & SIS (USA) & $=0.912$ & ICV (Poland) & $=6.630$ \\
\hline & ISI (Dubai, UAI & $=0.829$ & РИНЦ (Russia & $=0.156$ & PIF (India) & $=1.940$ \\
\hline & GIF (Australia) & $=0.564$ & ESJI (KZ) & $=8.716$ & IBI (India) & $=4.260$ \\
\hline & JIF & $=1.500$ & SJIF (Morocco & $=5.667$ & OAJI (USA) & $=0.350$ \\
\hline
\end{tabular}

Fig. 8. The assembly drawing of the trimming die for performing of the seventh step of drawing of the part "Case" is presented in the Fig. 9. The assembly drawing of the sizing die for performing of the eighth step of drawing of the part "Case" is presented in the Fig. 10.

The some steps of the technological process of drawing of the part "Case" are imprinted in the photos

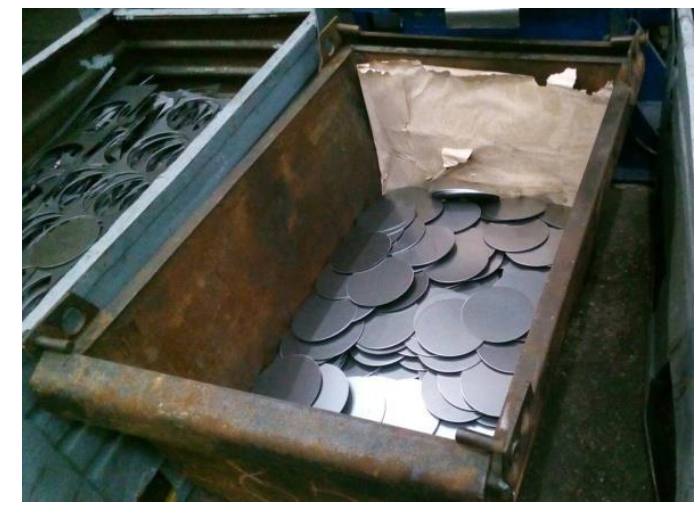

A)

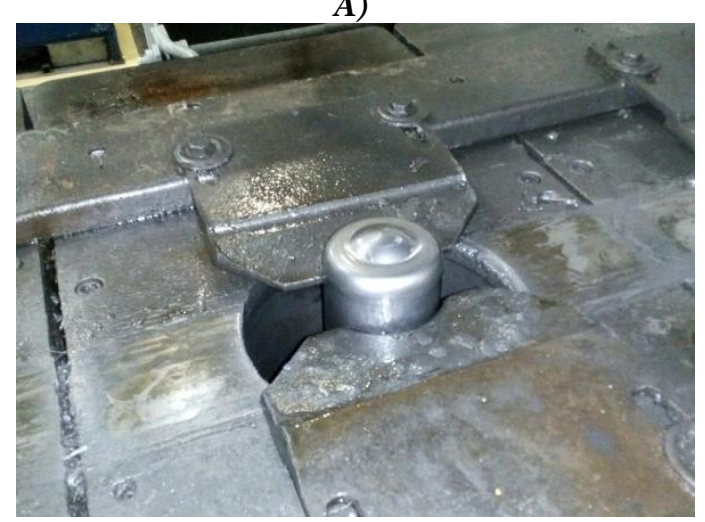

C) (the Fig. 11). Sampling rate for the sizes control is carried out through each 5 parts. The operations of the flange trimming on a turret lathe, cutting down of transverse holes and final calibration of a bottom of the thin-walled part were not considered in the technological process.

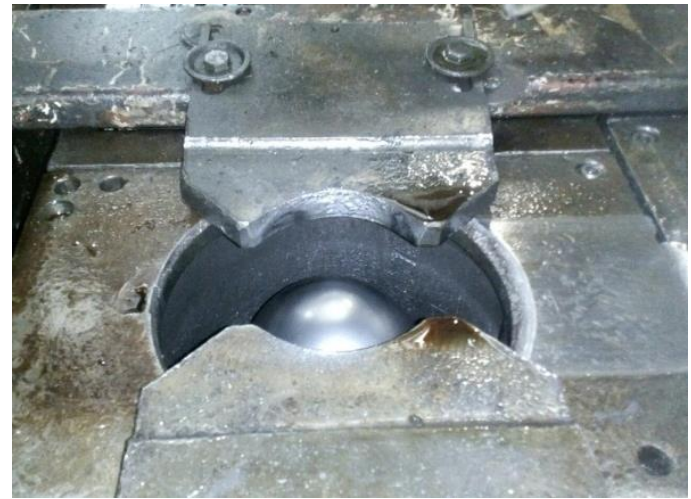

B)

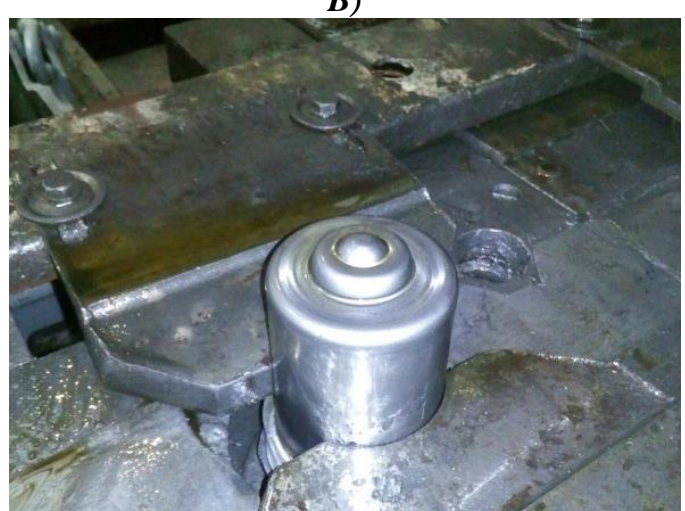

D)

Figure 11 - The technological process of the part drawing: $A$ - the container with the sheet billets, $B$ - the sheet billet after plastic deformation on the first step of the operation $015, C$ - the sheet billet after plastic deformation on the fourth step of the operation $015, D$ - the sheet billet after plastic deformation on the seventh step of the operation 015 .

Visual inspection of two hundred processed parts was carried out. Defects on one part were detected after multi-step drawing. Visual inspection of the parts revealed the following defects in descending order:

1. Deep dents on the outer surface.

2. Significant reduction of the size of wall thickness.

3. Wrinkles on the outer and inner surfaces.

4. Protruding burrs on the outer surface.

So as the considered part is not responsible then the detected defects do not significantly affect on its operation in an assembly unit.

\section{Conclusions}

On the basis of the considered technological process of manufacturing of the part "Case", and in particular the operation of multi-step deep drawing of the sheet billet, the following conclusions can be drawn:

1. In constructions of the proposed dies, supply of lubricating fluid to the surfaces of the sheet billet is provided for the calibration steps of the drawing process. This contributes to easier removing of the deformed sheet billet from the punch. On the remaining steps of drawing, removing of the sheet billet from the die is provided by the unstucker.

2. The defects of the part material after forming is approximately $1 \%$ (from a whole batch). Thus, the proposed technology of manufacturing of the part "Case" is acceptable in conditions of serial production. 


\begin{tabular}{llllll} 
& ISRA (India) $=\mathbf{3 . 1 1 7}$ & SIS (USA) & $=\mathbf{0 . 9 1 2}$ & ICV (Poland) & $=\mathbf{6 . 6 3 0}$ \\
Impact Factor: & ISI (Dubai, UAE) $=\mathbf{0 . 8 2 9}$ & PUHL (Russia) $=\mathbf{0 . 1 5 6}$ & PIF (India) & $=\mathbf{1 . 9 4 0}$ \\
& GIF (Australia) $=\mathbf{0 . 5 6 4}$ & ESJI (KZ) & $=\mathbf{8 . 7 1 6}$ & IBI (India) & $=\mathbf{4 . 2 6 0}$ \\
& JIF & $\mathbf{1 . 5 0 0}$ & SJIF (Morocco) $=\mathbf{5 . 6 6 7}$ & OAJI (USA) & $\mathbf{0 . 3 5 0}$ \\
\hline
\end{tabular}

\section{References:}

1. Chemezov, D. A. (2015). The research of the shallow drawing process of the plate stock. ISJ Theoretical \& Applied Science, 10 (30), $11-15$.

2. Chemezov, D. A., Seliverstov, V. S., Komisar, A. S., Zezina, N. A., \& Tyurina, S. I. (2015). Stamping of the plate stock with blank holder: the character of the material deformation and calculation of the coefficient of elongation. ISJ Theoretical \& Applied Science, 11 (31), 101 107.

3. Chemezov, D. A. (2015). Changing the wall thickness of the hollow detail during a shallow drawing of the plate stock. ISJ Theoretical \& Applied Science, 12 (32), 34 - 37.

4. Chemezov, D. A., Seliverstov, V. S., Bayakina, A. V., \& Zezina, N. A. (2016). The influence of the magnitude of the radius chamfer in the die hole on the degree of deformation of the processed material and the productivity of the deep drawing process of the plate stock. ISJ Theoretical \& Applied Science, 01 (33), $52-57$.

5. Chemezov, D. A., Smirnova, L. V., Seliverstov, V. S., \& Zezina, N. A. (2016). Comparison of stress-strain state of thin-walled detail after deep drawing of the direct and reverse methods. ISJ Theoretical \& Applied Science, 03 (35), $21-25$.

6. Chemezov, D. A., Smirnova, L. V., \& Seliverstov, V. S. (2016). The calculation of the sizes of the plate stock for the processing of thinwalled details of the square shape by the method of deep drawing. ISJ Theoretical \& Applied Science, 04 (36), 111 - 114.

7. Chemezov, D. A. (2016). The drawing of the plate stock without blank holder. ISJ Theoretical \& Applied Science, 07 (39), $1-6$.

8. Chemezov, D., \& Lukyanova, T. (2017). A determination of the strain state of the thinwalled hollow detail of square shape after the drawing of the sheet metal with the blank holder. ISJ Theoretical \& Applied Science, 01 (45), 64 66.

9. Chemezov, D. A. (2016). The calculation of the maximum stress of thin-walled detail while performing the technological process of deep drawing of the plate stock. Fundamental and applied researches in the modern world. Materials XIII of the International scientific and practical conference, Volume 1, 36-39.

10. Chemezov, D. A., Seliverstov, V. S., \& Zezina, N. A. (2016). Analysis of the technological process of deep drawing of a thin-walled part: processing modes, sizes of forming tools and rejects. International scientific journal "Young scientist", №4, $101-105$.

11. Chemezov, D. A., \& Seliverstov, V. S. (2015). The intensity of the formation of corrugation on the flange of the deformable plate stock of thickness $1-5 \mathrm{~mm}$. Scientific and theoretical journal "System engineering", №2, $71-76$.

12. Chemezov, D. A., Zezina, N. A., \& Seliverstov, V. S. (2015). The determination of the bending moment at the pressure of the punch on the material in the conditions of the shallow drawing of the plate stock. Fundamental and applied researches in the modern world. Materials XII of the International scientific and practical conference, Volume 1, 73-76.

13. Chemezov, D. A., Seliverstov, V. S., \& Kondrakov, A. A. (2015). The process of corrugations formation on a flange of deformable sheet material. Scientific and practical journal "Journal of scientific and applied researches", №10, $79-81$.

14. GOST 19904-90. Cold-rolled steel sheets. Dimensions. 